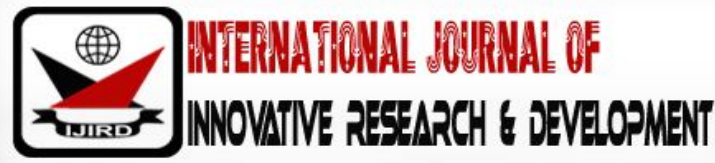

ISSN 2278 - 0211 (Online)

\section{Effect of Infrastructural Facilities on SMEs Growth in Nigeria}

\author{
Akinlemi Omololu Akinson \\ Research Student, Lagos State University, Nigeria
}

\begin{abstract}
:
Small and medium scale enterprises are engine of economic growth. SMEs growth in Nigeria has been inhibited by the dearth of infrastructural facilities in the country. These facilities range from power supply, water supply, road and rail network, telecommunication, health facilities and so on. Provision of these facilities is the responsibility of government but almost all these facilities are in short supply or inadequate in Nigeria. This situation has negatively affected the performance of SMEs in the Nigerian economy. This study examines the effect of infrastructural facilities on performance of SMEs in Nigeria. The research methodology adopted is the quantitative research methodology. A survey research design was used and a judgmental and convenience sampling procedure was applied in collecting data from 200 respondents selected from four major SMEs clusters in Lagos. The data collected with the use of questionnaires were analyzed with percentages and chisquare for testing hypothesis formulated for the study. The results obtained shows that many small and medium scale operators in Nigeria provide for the basic infrastructure themselves. The huge cost involves in providing this basic amenity has put out many small and medium scale business operators out of business. Infrastructure like power and water are the life wire of any business enterprises. Therefore, small and medium scale business enterprises need infrastructural facilities to grow.
\end{abstract}

Keywords: Infrastructure, SMEs

\section{Introduction}

Infrastructure as defined by Wikipedia refers to structures, systems, and facilities serving the economy of a business, industry, country, city, town, or area, including the services and facilities necessary for its economy to function. It is typically a term to characterize the existence or condition of costly 'technical structures' such as roads, bridges, tunnels, or other constructed facilities such as loading docks, cold storage chambers, electrical capacity, fuel tanks, cranes, overhead clearances, or components of water supplies, sewers, electrical grids, telecommunications, and so forth. Infrastructure thus consists of improvements with significant cost to develop or install that return an important value over time. As stated by Olanrewaju (2011) in the speech he delivered on "infrastructure-key challenge for SMEs" says that, you cannot separate infrastructure from Small and Medium Scale Enterprises (SMEs). Simply because without infrastructure, SMEs or even large companies will find it hard to survive. Infrastructural facilities available in a particular country will help provide an enabling environment for small and medium scale enterprises. This is because, it facilitates the production and distribution of goods and services to the market. These facilities mostly provided by government constitute the social amenities like good road network, power supply, telecommunication, water, health care facilities and other things that bring about a conducive atmosphere for business operations. A comprehensive list of infrastructural facilities needed by Small and Medium Scale Enterprises includes the following.

- Good road network linking the city center and rural areas.

- Railway systems

- Navigable waterways and canals

- Electricity

- Good and constant water supply

- Good drainage system

- Irrigation system

- Telephone and mobile phones network

- Warehouse facilities 
- Industrial parks

- Agricultural produce storage facilities

- Good health care systems.

Basically, government is the major provider of infrastructural facilities, this is because of the huge cost involved in putting them in place and the need to make the services affordable to the general public. In recent times, private organizations now provide some of the basic infrastructure needed by the public. The services rendered come at a higher cost as the firms needs to make reasonable profit from their investments. The implication of this for Small and Medium Scale Enterprises is that, since most of the infrastructural facilities they require are provided by private business men or they themselves, the cost for those services becomes expensive compared with when they are provided by government and this will definitely drive up the cost of doing business.

\subsection{Statement of the Problem}

Nigeria as a country is suffering from an infrastructural deficit. Government has not done enough to create the best conducive environment that will encourage small and large businesses. Early this year, President Muhammodu Buhari declared a state of emergency on the state of infrastructure in the country. He contended that, the nation can come out of economic recession if considerable amount is spent investing on infrastructure as this will open up the Nigerian economy and create an atmosphere that will enable businesses to strive. The problem of infrastructures in Nigeria presently ranges from shortage of power supply which includes electricity and gas, inadequate road networks and transport systems, lack of improper solid waste management and a whole lot of others. Nigeria's underdevelopment of both physical and social infrastructures has hindered the growth of Small and Medium Scale Enterprises in the country. Many small and medium scale enterprises provide for basic infrastructure themselves, those who cannot provide for it are either force out of business or cling to the inefficiently provided state infrastructures. This situation depicts the reality faced by SMEs operators in Nigeria and it is high time the government woke up to his responsibilities.

\subsection{Objective of the Study}

The objective of the study is to ascertain the effect of infrastructural facilities towards the growth of small and medium scale enterprises in Nigeria.

\subsection{Research Question}

What is the effect of infrastructural facilities towards the growth of small and medium scale enterprises in Nigeria?

\subsection{Research Hypothesis}

- HO: Infrastructural facilities do not affect the growth and development of small and medium scale enterprises in Nigeria.

\section{Literature Review}

\subsection{Definitions of Small and Medium Scale Enterprises}

The acronym SMEs means Small and Medium Scale Enterprises. There is no universal definition for SMEs. Different countries have used some criterias to define SME. These include turnover, number of employees, working capital and the likes.

According to (Abereijo, Ilori, Taiwo and Adegbite, 2007). SMEs can be defined based on the number of employees, capital invested and turnover. The definition of SMEs is usually derived in each country, based on the role of SME in the economy, policies and programs designed by particular agencies or institutions empowered to develop SME. For instance, a small business in the developed economies of countries like Japan, Germany and United States of America, may be a medium or large scaled business in a developing economy like Nigeria. Moreover, the definition of SME also varies overtime from agencies or developing institutions to another, depending on their policy focus (Etuk, Etuk, and Baghebo, 2014).

Most Small and Medium Scale Enterprises started as a micro business enterprise then thereafter to a largescale enterprise. All these various business sectors contribute in different degrees to the growth and development of the economy.

CBN (2005) defines the various sectors as follows:

\subsubsection{Micro/ Cottage Industry}

An industry with a labour size of not more than 10 workers or total cost not more than N1.50 million including working capital but excluding cost of land

\subsubsection{Small Scale Industry}

An industry with a labour size of between 11-100 workers or a total cost of not more than N50 million including working capital but excluding cost of land 


\subsubsection{Medium Scale Industry}

An industry with a labour size of between 101-300 workers or a total cost of over N50 million but not more than N200 million, including working capital but excluding cost of land

\subsubsection{Large Scale}

An industry with a labour size of over 300 workers or a total cost of over N200 million, including working capital but excluding cost of land.

The National Enterprise Development Programme (NEDEP, 2014), define Small Enterprise as an enterprise with 10-40 employees with asset (excluding land and buildings) between N5 million to less than N50 million. While a medium Enterprises as an enterprise with 50 - 199 employees with asset (excluding land and buildings) between N50 million to less than N500 million.

\subsection{Effect of Infrastructural Facilities on SMEs}

Many research works have identified infrastructural facilities as one of the major factor that determines the growth and development of the SMEs sector of the economy. This fact has been buttressed over and over again. In the research conducted by Adigwe (2012) in his work "Project Finance for Small and Medium Scale Enterprises (SMEs) in Nigeria" he stated that, the provision of basic infrastructure like power, education, water, roads, and transportation is the minimum requirement for SMEs to flourish. Osoba (2003) argues that the infrastructural facilities provided by government helps the growth of small scale business by facilitating the accusation of required inputs, these facilities are the essential infrastructures that assist and promote investment. Some of them are; Provision of access roads; Increased improvement in communication facilities like telephone, postal services, NITEL, etc; Provision and expansion of electricity; Water expansion schemes to service industrial of business sites. Construction of industrial layouts/ estates; Establishment and maintenance of an Export Processing Zone (EPZ). The provision of all these facilities help the small-scale business to expand through quick movement of goods and services, expansion of markets for products and lead to a relatively cheaper investment cost. Ben, Faboyede, and Fakile. (2013) citing Ojo (2006) concludes that, inadequate infrastructural base coupled with the decay or deplorable conditions of the available ones has posed formidable obstacle to small and medium scale enterprises performance and hence calls for urgent attention by the government. Bitrus and Ahmed (2014) stated that, the infrastructural facilities in many developing countries is grossly inadequate which had led to private provisioning of these facilities and which is at a huge cost which reduces the funds available for their activities.

Experts argue that the infrastructural facilities created by government helps in the growth of small scale business, by facilitating the acquisition of required inputs. These facilities are, the essential infrastructures that assist and promote investment and growth of the SMEs (Ogechukwu, Oboreh, Umukoro \& Uche, 2013).

Imoisi and Ephraim (2012) citing Osoba (2003) emphasize that, the problem of unstable and unreliable supply of electricity, dilapidated roads, inadequate supply of water for both home and industrial use, inefficient and costly communication system, among others, have for long hindered the growth and development of SMEs in Nigeria. Nearly all SME operating in Nigeria have one or more power generating plants as an alternative source of power supply. The cost of obtaining, maintaining, sustaining and managing such generating plants are more often than not very expensive and this has made cost of production as well as prices of product very expensive, with the latter turning out to be more and more uncompetitive in comparison with the imported equivalent. It is estimated that, the cost of providing basic infrastructural amenities is $5 \%$ to $20 \%$ of the total cost of setting up a manufacturing and processing industry in Nigeria.

The SMEs sector in Nigeria is burdened by high cost of operations which reduces the profitability of many businesses and their ability to remain going concerns. Key elements contributing to the high cost of operations are infrastructural costs and levies \& other administrative costs. The main infrastructural cost that SMEs have to contend with include: power, logistics, water, sanitation and social amenities (National Policy on SMEs, 2013).

Ugwushi (2009) compared the level at which infrastructural inadequacy and lack of social support lead to SMEs failure in the UK and Nigeria. and the results revealed that 60 percent of the UK respondents chose a little extent and 29 percent chose an average extent. In Nigeria, 27 percent chose to a large extent and 60 percent chose to a very large extent. This implies that infrastructural inadequacy is considered very minimal in the UK though it is seen as a very crucial factor influencing SMEs failure. Agu and Imeti (2014) in their research "Issues, Challenges and Prospects of Small and Medium Scale Enterprises (SMEs) in Port-Harcourt City, Nigeria" also conclude that inadequate social infrastructures constitute a major challenge in the performance of SMEs in Port-Harcourt City.

Mohammed and Bashir (2013) opined that, infrastructural facilities such as transportation networks, pipe borne water, electricity, security, telecommunication, etc. encourages the establishment, operations and growth of SMEs when they are provided in the required quantity and maintained consistently. This is hardly the case in Nigeria. Power supply to SMEs in the country is sporadic and grossly inadequate for use in industries. Nigeria's power stations as at year 2003 is estimated at 5,400 Megawatts (MW) but only 1600 (29\%) MW is actually generated. Mohammed and Bashir (2013) citing Ajanaku (2007) reveals that Nigeria needs 375,000 MW to meet up with the global standard. He argued that using less than 3000 MW produced in Nigeria between 4th and 1st quarter of 2007 and 2008 respectively, translates to 27 $\mathrm{KW} / \mathrm{hr}$ per person which is far below the world per capita consumption of $2500 \mathrm{kw} / \mathrm{hr}$ per person. Thus, for survival 
purposes, operators of SMEs supplement power supplies from the national grid with standby generators at exorbitant procurement and maintenance costs/prices that inflate the final prices of the manufactured products against the imported products and making them less competitive.

Presently the power generation in Nigeria is still between 3000 and 5000 Megawatts. There has not been any significant improvement over the years. SMEs must strive to adapt to this severe situation if they are to remain in business. The president has promised to increase the power generation to 10,000 megawatts by 2018, whether this target will be realized and achievable depends on government commitment to the plight of the general public and businessmen at large.

The SMEs sector is the driving force of a nation's economy. Developed countries of the world have invested heavily on infrastructural facilities and the maintenance of existing ones. Nations like US, UK, China, Japan, Canada and the Asian Tigre Nations have over the years increased their infrastructural base which have opened up opportunities for new businesses and thereby accelerating their economic development.

\section{Methodology}

The survey research design was adopted for this study. This research made use of both primary and secondary data. The primary data were collected via the use of a questionnaire. The secondary sources of data for this study includes information gotten from textbooks, journals, newspapers etc. The field work of this study was conducted in Lagos State Nigeria. The study population comprises all SMEs in Nigeria. The judgmental and the convenience non-probability sampling method was used to draw samples from the population. A sample size of 200 was evenly selected from Four SMEs clusters in Lagos which includes: The Otigba ICT SME cluster in Ikeja Local Government, The Alaba International SME cluster in Ojo Local Government, The Auto Spare Part and Machinery Dealers Association (ASPAMDA) SME cluster in Amuwo Odofin Local Government and The Printing SME cluster in Shomolu Local Government. Questionnaires were distributed to each selected SMEs cluster and out of a total of 200, only 171 questionnaires were returned. The data collected through questionnaire was analysed using simple percentages and chi-square with the aid of Statistical Packages for Social Science (SPSS).

\section{Data Analysis and Interpretation}

\begin{tabular}{|c|c|c|c|c|c|c|}
\hline Code & Nature of Business & Position Held & Sex & Age & Marital Status & Educational Qualification \\
\hline 1 & ICT & Owner & Male & $20-27$ & Single & S.S.C.E \\
\hline 2 & Printing & Manager & Female & $28-35$ & Married & OND/ NCE \\
\hline 3 & Electronics & Supervisor & & $36-43$ & Divorced & B.SC./ HND \\
\hline 4 & $\begin{array}{c}\text { Auto Parts and } \\
\text { Machinery }\end{array}$ & & & $\begin{array}{c}44 \text { and } \\
\text { above }\end{array}$ & & Master Degree and above \\
\hline
\end{tabular}

Table 1: Coding of Demographic Variables

(Source: The Author, 2016)

\begin{tabular}{|c|c|c|c|c|c|c|c|c|c|}
\hline & & \multicolumn{8}{|c|}{ Sectors } \\
\hline & & \multicolumn{2}{|c|}{ ICT } & \multicolumn{2}{|c|}{ Printing } & \multicolumn{2}{|c|}{ Electronics } & \multicolumn{2}{|c|}{ Autoparts } \\
\hline Variables & Parameters & & $\%$ & & $\%$ & & $\%$ & & $\%$ \\
\hline \multirow[t]{4}{*}{ Position Held } & Owner & 13 & 28.3 & 12 & 30.8 & 15 & 30.8 & 10 & 23.8 \\
\hline & Manager & 22 & 47.8 & 19 & 48.7 & 16 & 48.7 & 23 & 54.8 \\
\hline & Supervisor & 11 & 23.9 & 8 & 20.5 & 13 & 20.5 & 9 & 21.4 \\
\hline & Total & 46 & 100 & 39 & 100 & 44 & 100 & 42 & 100 \\
\hline \multirow[t]{3}{*}{ Sex } & Male & 32 & 69.6 & 28 & 71.8 & 28 & 71.8 & 29 & 69.0 \\
\hline & Female & 14 & 30.4 & 11 & 28.2 & 16 & 28.2 & 13 & 31.0 \\
\hline & Total & 46 & 100 & 39 & 100 & 44 & 100 & 42 & 100 \\
\hline \multirow[t]{5}{*}{ Age } & $20-27$ & 5 & 10.9 & 1 & 2.6 & 3 & 2.6 & 4 & 9.5 \\
\hline & $28-35$ & 21 & 45.7 & 15 & 38.5 & 20 & 38.5 & 15 & 35.7 \\
\hline & $36-43$ & 12 & 26.1 & 12 & 30.8 & 13 & 30.8 & 14 & 33.3 \\
\hline & 44 above & 8 & 17.4 & 11 & 28.2 & 8 & 28.2 & 9 & 21.4 \\
\hline & Total & 46 & 100 & 39 & 100 & 44 & 100 & 42 & 100 \\
\hline \multirow[t]{4}{*}{ Marital Status } & Single & 19 & 41.3 & 11 & 28.2 & 15 & 28.2 & 14 & 33.3 \\
\hline & Married & 19 & 41.3 & 21 & 53.8 & 22 & 53.8 & 20 & 47.6 \\
\hline & Divorced & 8 & 17.4 & 7 & 17.9 & 7 & 17.9 & 8 & 19.1 \\
\hline & Total & 46 & 100 & 39 & 100 & 44 & 100 & 42 & 100 \\
\hline \multirow[t]{5}{*}{ Educational Qualification } & S.S.C.E & 3 & 6.5 & 1 & 2.6 & 2 & 2.6 & 3 & 7.1 \\
\hline & OND/ NCE & 15 & 32.6 & 10 & 25.6 & 13 & 25.6 & 12 & 28.6 \\
\hline & Degree/ HND & 21 & 45.7 & 22 & 56.4 & 22 & 56.4 & 23 & 54.8 \\
\hline & Masters above & 7 & 15.2 & 6 & 15.4 & 10 & 15.4 & 4 & 9.6 \\
\hline & Total & 46 & 100 & 39 & 100 & 44 & 100 & 42 & 100 \\
\hline
\end{tabular}

Table 2: Demographic Analysis of Each Sector

(Source: The Author, 2016 


\subsection{Analysis of All the Responses for Research Data}

The aggregate of the responses for all the research questions are collated and analyzed using percentage analysis. These analyses have helped to provide answers to the research question and help in achieving the objectives for this study. Below are the tables for each analysis:

\begin{tabular}{|c|c|c|c|c|c|}
\hline \multicolumn{2}{|c|}{} & Frequency & Percent & $\begin{array}{c}\text { Valid } \\
\text { Percent }\end{array}$ & $\begin{array}{c}\text { Cumulative } \\
\text { Percent }\end{array}$ \\
\hline \multirow{2}{*}{$\begin{array}{c}\text { Vali } \\
\mathrm{d}\end{array}$} & $\begin{array}{c}\text { Strongly } \\
\text { Disagree }\end{array}$ & 19 & 11.1 & 11.1 & 11.1 \\
\cline { 2 - 6 } & Disagree & 3 & 1.8 & 1.8 & 12.9 \\
\cline { 2 - 6 } & Undecided & 24 & 14.0 & 14.0 & 26.9 \\
\cline { 2 - 6 } & Agree & 45 & 26.3 & 26.3 & 53.2 \\
\cline { 2 - 6 } & $\begin{array}{c}\text { Strongly } \\
\text { Agree }\end{array}$ & 80 & 46.8 & 46.8 & 100.0 \\
\cline { 2 - 6 } & Total & 171 & 100.0 & 100.0 & \\
\hline
\end{tabular}

Table 3: Nigeria Can Attain Economic Growth and Development If SMEs

Have Access to the Necessary Infrastructural Facilities

(Source: SPSS Version 20)

From table 4.3.11, 125 (73.1\%) of the respondent agreed to this assertion, while 22 (12.9\%) disagreed and 24 (14\%) were undecided. The majority of the respondent agreed to the statement and this implies that availability of infrastructural facilities for SMEs can bring about economic growth and development in Nigeria.

\begin{tabular}{|c|c|c|c|c|c|}
\hline \multicolumn{2}{|c|}{} & Frequency & Percent & $\begin{array}{c}\text { Valid } \\
\text { Percent }\end{array}$ & $\begin{array}{c}\text { Cumulative } \\
\text { Percent }\end{array}$ \\
\hline \multirow{3}{*}{ Valid } & Strongly Disagree & 29 & 17.0 & 17.0 & 17.0 \\
\cline { 2 - 6 } & Disagree & 23 & 13.5 & 13.5 & 30.4 \\
\cline { 2 - 6 } & Undecided & 19 & 11.1 & 11.1 & 41.5 \\
\cline { 2 - 6 } & Agree & 67 & 39.2 & 39.2 & 80.7 \\
\cline { 2 - 6 } & Strongly Agree & 33 & 19.3 & 19.3 & 100.0 \\
\cline { 2 - 6 } & Total & 171 & 100.0 & 100.0 & \\
\hline
\end{tabular}

Table 4: Despite the Shortfall in Power Supply, SMEs Still Strives

(Source: SPSS Version 20)

As seen in the table above, the 100 (58.5\%) of respondent agreed with the statement. This point to the fact that all SMEs operating in Nigeria provides for power themselves if they are to remain in business. And the $52(30.5 \%)$ of the respondent who disagrees suggest that shortage of power supply in the country has put off many SMEs out of business as they cannot cope with high running cost. Also 19 (11.1\%) that were undecided could not say precisely the impact of this problem.

\begin{tabular}{|c|c|c|c|c|c|}
\hline \multicolumn{2}{|c|}{} & Frequency & Percent & $\begin{array}{c}\text { Valid } \\
\text { Percent }\end{array}$ & $\begin{array}{c}\text { Cumulative } \\
\text { Percent }\end{array}$ \\
\hline \multirow{3}{*}{ Valid } & $\begin{array}{c}\text { Strongly } \\
\text { Disagree }\end{array}$ & 35 & 20.5 & 20.5 & 20.5 \\
\cline { 2 - 6 } & Disagree & 45 & 26.3 & 26.3 & 46.8 \\
\cline { 2 - 6 } & Undecided & 40 & 23.4 & 23.4 & 70.2 \\
\cline { 2 - 6 } & Agree & 38 & 22.2 & 22.2 & 92.4 \\
\cline { 2 - 6 } & Strongly Agree & 13 & 7.6 & 7.6 & 100.0 \\
\cline { 2 - 6 } & Total & 171 & 100.0 & 100.0 & \\
\hline
\end{tabular}

Table 5: Some SMEs Do Not Require Infrastructural and Social Amenities to Operate

(Source: SPSS Version 20)

From table 4.3.13, 80 (46.8\%) of respondent disagreed, 51 (29.8\%) agreed and 40 (23.4\%) of the respondent were undecided. since majority of the respondent disagreed, this is a pointer to the fact that, SMEs requires infrastructural and social amenities to operate. 


\begin{tabular}{|c|c|c|c|c|c|}
\hline \multicolumn{2}{|c|}{} & Frequency & Percent & $\begin{array}{c}\text { Valid } \\
\text { Percent }\end{array}$ & $\begin{array}{c}\text { Cumulative } \\
\text { Percent }\end{array}$ \\
\hline Valid & $\begin{array}{c}\text { Strongly } \\
\text { Disagree }\end{array}$ & 5 & 2.9 & 2.9 & 2.9 \\
\cline { 2 - 6 } & Disagree & 21 & 12.3 & 12.3 & 15.2 \\
\cline { 2 - 6 } & Undecided & 14 & 8.2 & 8.2 & 23.4 \\
\cline { 2 - 6 } & Agree & 61 & 35.7 & 35.7 & 59.1 \\
\cline { 2 - 6 } & $\begin{array}{c}\text { Strongly } \\
\text { Agree }\end{array}$ & 70 & 40.9 & 40.9 & 100.0 \\
\cline { 2 - 6 } & Total & 171 & 100.0 & 100.0 & \\
\hline
\end{tabular}

Table 6: Many Economies Developed through SMEs Possess Large Scale of Infrastructural Facilities That Support Business Activities

(Source: SPSS Version 20)

The responses from this table above shows that 131 (76.6\%) of the respondent agreed, while 26 (15.2\%) disagreed and $14(8.2 \%)$ disagreed with the statement. Since the majority of the respondent agreed to this assertion, it therefore implies that, for a country to be developed economically, it must invest in infrastructural facilities.

\begin{tabular}{|c|c|c|c|c|c|}
\hline \multicolumn{2}{|c|}{} & Frequency & Percent & $\begin{array}{c}\text { Valid } \\
\text { Percent }\end{array}$ & $\begin{array}{c}\text { Cumulativ } \\
\text { e Percent }\end{array}$ \\
\hline \multirow{3}{*}{$\begin{array}{c}\text { Vali } \\
\mathrm{d}\end{array}$} & Disagree & 6 & 3.5 & 3.5 & 3.5 \\
\cline { 2 - 6 } & Undecided & 12 & 7.0 & 7.0 & 10.5 \\
\cline { 2 - 6 } & Agree & 44 & 25.7 & 25.7 & 36.3 \\
\cline { 2 - 6 } & $\begin{array}{c}\text { Strongly } \\
\text { Agree }\end{array}$ & 109 & 63.7 & 63.7 & 100.0 \\
\cline { 2 - 6 } & Total & 171 & 100.0 & 100.0 & \\
\hline
\end{tabular}

Table 7: Good Road Network Can Open up New Markets for

Small and Medium Scale Enterprises

(Source: SPSS Version 20)

From table 4.3.15, which emphasizes a major infrastructure a country needs to put in place, we can see that, almost all the respondent agreed to statement. This further confirms that good road network in the country can open up new markets and enhance small scale business enterprises.

\subsection{Test of Research Hypothesis}

- HO: Infrastructural facilities does not affect the growth and development of small and medium scale enterprises in Nigeria.

\begin{tabular}{|c|c|c|c|c|c|}
\hline Comment & $\begin{array}{c}\text { Nigeria can attain } \\
\text { economic growth and } \\
\text { development if SMEs } \\
\text { have access to the } \\
\text { necessary infrastructural } \\
\text { facilities. }\end{array}$ & $\begin{array}{c}\text { Despite the } \\
\text { shortfall in } \\
\text { power supply, } \\
\text { SMEs still } \\
\text { strives. }\end{array}$ & $\begin{array}{c}\text { Some SMEs } \\
\text { do not } \\
\text { require } \\
\text { infrastructur } \\
\text { al and social } \\
\text { amenities to } \\
\text { operate. }\end{array}$ & $\begin{array}{c}\text { Many economies } \\
\text { developed } \\
\text { through SMEs } \\
\text { possess large } \\
\text { scale of } \\
\text { infrastructural } \\
\text { facilities that } \\
\text { support business } \\
\text { activities. }\end{array}$ & $\begin{array}{c}\text { Good road } \\
\text { network can } \\
\text { open up new } \\
\text { markets for } \\
\text { small and } \\
\text { medium scale } \\
\text { enterprises. }\end{array}$ \\
\hline Chi-Square & $103.006^{a}$ & $42.713^{a}$ & 17.977 a & $100.433^{\mathrm{a}}$ & $156.415^{\mathrm{b}}$ \\
\hline df & 4 & 4 & 4 & 4 & 3 \\
\hline Asymp. Sig. & .000 & .000 & .001 & .000 & .000 \\
\hline
\end{tabular}

Table 8: Chi-Square Test Statistics

(Source: SPSS Version 20)

a. 0 Cells (0.0\%) Have Expected Frequencies Less Than 5; the Minimum Expected Cell Frequency Is 34.2

b. 0 Cells (0.0\%) Have Expected Frequencies Less Than 5; the Minimum Expected Cell Frequency Is 42.8

\subsubsection{Decision Rule}

Since the value of the significant level of the hypothesis is less than 0.05 in all the five questions used in testing the hypothesis, we reject the null hypothesis Ho and concludes that Infrastructural facilities affect the growth and development of small and medium scale enterprises in Nigeria. 


\subsection{Summary}

In the works of Ugwushi (2009), he found out that infrastructural inadequacy and lack of social support is considered a crucial factor influencing SMEs failure. This position is supported in this study as show in table 4.3.13 where majority of the respondent indicated that SMEs require infrastructural and social amenities to operate successfully. Though many SMEs provide for these themselves which has actually increased their operating cost. but since the government has not been able to provide these facilities such as power and water supply, they are left with no option than to provide it themselves. The erratic power supply in the country is not helping the SMEs sector. As seen in the table 4.3.12 on the question about power supply, the $100(58.5 \%)$ of respondent agreed with the statement. This point to the fact that all SMEs operating in Nigeria provides for power themselves if they are to remain in business. And the 52 (30.5\%) of the respondent who disagrees suggest that shortage of power supply in the country has put off many SMEs out of business as they cannot cope with high running cost. Also 19 $(11.1 \%)$ that were undecided could not say precisely the impact of this problem.

\section{Conclusion}

Many small and medium scale operators in Nigeria provide for the basic infrastructure themselves. The huge cost involves in providing this basic amenity has put out many small and medium scale business operators out of business. Infrastructure like power and water are the life wire of any business enterprises. Therefore, small and medium scale business enterprises need infrastructural facilities to grow.

\section{Recommendations}

- Government can exploit opportunities available in telecommunications by opening up the telecommunications industry for more telecoms company as this will create business opportunities for SMEs.

- Transportation by rail provide the cheapest means of transporting goods and services for SMEs. The rail routes in the country should be upgraded and expanded.

- The industrial parks across the country are not in good condition. Government should renovate the existing ones and build more parks that will provide the different facilities needed by SMEs.

- Government should invest heavily on power generation from different sources to increase power supply across the country.

- Many roads in urban areas and the interstate roads are in an abysmal state. Government should ensure proper maintenance of roads and build up new ones.

- SMEs need water supply to function properly, both federal and state water corporations should discharge their responsibilities of providing water for the society at large.

\section{References}

i. Abereijo,O. Ilori, O. Taiwo,A. and Adegbite, A. (2007). Assessment of the capabilities for innovation by small and medium industry in Nigeria. African journal of business management vol 1(8), pp.209-217.

ii. Adegbite E. O. (1995), Effective Growth and Survival of Small and Medium ScaleEnterprises in the 1990s and Beyond. The Role of Policy in Ade T. Ojo (eds) Management of SMEs in Nigeria. Punmark Nig. Ltd, Lagos.

iii. Adikwe, P.K. (2012).Project Finance for Small and Medium Scale Enterprises (SMEs) in

iv. Nigeria. An International Multidisciplinary Journal, Ethiopia, Vol. 6 (1), ISSN 1994- 9057 (Print) ISSN 2070--0083 (Online)

v. Agwu, M.O., IMETI,C.I.(2014).Issues, Challenges and Prospects of Small and Medium Scale Enterprises (SMEs) in PortHarcourt City, Nigeria. European Journal of Sustainable Development (2014), 3, 1, 101-114 ISSN: 2239-5938.

vi. Ajanaku, L. (2007), Power Paralysis,Tell, No. 17, November 19.

vii. Ayozie, D.O.Jacobs, S.O.,Umukoro,F.,Ayozie,V.U.(2013). Small and medium scale enterprises in Nigeria the marketing interface. Global journal of management and business research Vol 13 issue 9.ISSN 09755853.

viii. Ben, C.E.,Faboyede, O.S., Fakile,.A.S. (2013).Empowering Small and Medium Scale Enterprises in Nigeria: A Key Poverty Alleviation Strategy.International Journal of Business and Management Invention. ISSN (Online): 2319 - 8028, ISSN (Print): 2319 - 801X.

ix. Bitrut, F.K.,Ahmed, I.K.(2014). Nature and Relevance of Small and Medium Scale Enterprises in the Economic Development of Nigeria.International Journal of Economic Development Research and Investment, Vol. 2, No. 2; August, 2011

x. Central Bank of Nigeria (2005).Micro finance policy regulation and supervisory framew ork of Nigeria

xi. Imoisi, A,I., Ephraim, J.(2012). Small and Medium Scale Enterprises and Economic Growth in Nigeria: 19752012.International Journal of Business and Management; Vol. 10, No. 3; 2015.

xii. Mohammed, A.M. and Bashir, D.S. (2013) Developing Nigeria Through Small ScaleEnterprises. Jorind 11(2). ISSN 1596-8303.

xiii. National Enterprise Development Program (2014)

xiv. Ojo, J.A.T (2006). Using SMEs to Achieve Millennium Development Goals: Challenges and Prospects.Covenant Journal of Business \& Social Sciences. 1(1) 20-35 
xv. Olanrewaju (2011), Infrastructure- Key Challenges For Smes. A speech delivered at the Enterprise Development Centre (EDC) $3^{\text {rd }}$ Alumni conference at the shell hall Muson Centre.

xvi. Ogechukwu ,D., Oboreh, J.S., Umukoro, F., Uche, A.V. (2013) SME in Nigeria the

xvii. Marketing Interface. Global journal of management and business research

xviii. marketing.Vol 13,Issue 9, ISSN 0975-5853

xix. Osoba, A. M. (2003). Towards the Development of Small Scale Industries in Nigeria.

xx. Nigerian Institute of Social and Economic Research.

xxi. Ugwuchi, B.I. (2009).SMEs Key Failure-Factors: A Comparison between the United Kingdom and

xxii. Nigeria.Journal of Social Sciences, 18(3): 199-207 (2009).

xxiii. Wikipedia (2016) "INFRASTRUCTURE", Free Encyclopedia 